\title{
Pardosa acorensis
}

\author{
Assessment by: Borges, P.A.V. \& Cardoso, P.
}

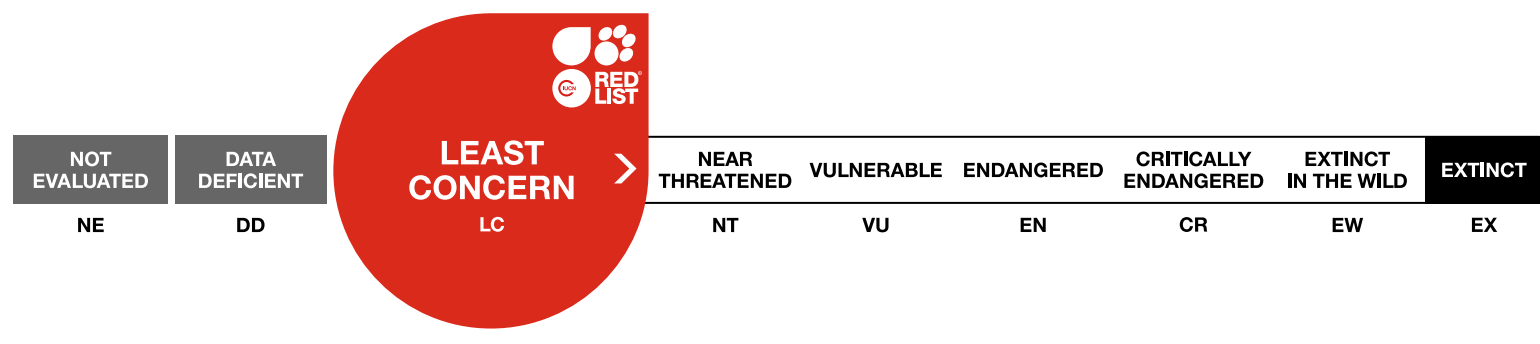

View on www.iucnredlist.org

Citation: Borges, P.A.V. \& Cardoso, P. 2020. Pardosa acorensis. The IUCN Red List of Threatened Species 2020: e.T58048677A58061032. https://dx.doi.org/10.2305/IUCN.UK.20203.RLTS.T58048677A58061032.en

Copyright: (C 2020 International Union for Conservation of Nature and Natural Resources Reproduction of this publication for educational or other non-commercial purposes is authorized without prior written permission from the copyright holder provided the source is fully acknowledged.

Reproduction of this publication for resale, reposting or other commercial purposes is prohibited without prior written permission from the copyright holder. For further details see Terms of Use.

The IUCN Red List of Threatened Species ${ }^{T M}$ is produced and managed by the IUCN Global Species Programme, the IUCN Species Survival Commission (SSC) and The IUCN Red List Partnership. The IUCN Red List Partners are: Arizona State University; BirdLife International; Botanic Gardens Conservation International; Conservation International; NatureServe; Royal Botanic Gardens, Kew; Sapienza University of Rome; Texas A\&M University; and Zoological Society of London.

If you see any errors or have any questions or suggestions on what is shown in this document, please provide us with feedback so that we can correct or extend the information provided. 


\title{
Taxonomy
}

\begin{tabular}{|c|c|c|c|c|}
\hline Kingdom & Phylum & Class & Order & Family \\
\hline Animalia & Arthropoda & Arachnida & Araneae & Lycosidae \\
\hline
\end{tabular}

Scientific Name: Pardosa acorensis Simon, 1883

\section{Taxonomic Source(s):}

Platnick, N.I. 2014. The World Spider Catalog, Version 14.5. P. Merrett \& H.D. Cameron (eds). American Museum of Natural History. Available at: http://research.amnh.org/iz/spiders/catalog/index.html. (Accessed: 31 March 2014).

\section{Assessment Information}

\author{
Red List Category \& Criteria: $\quad$ Least Concern ver 3.1 \\ Year Published: 2020 \\ Date Assessed: $\quad$ October 1, 2017
}

\section{Justification:}

Pardosa acorensis is a wolf spider species occurring on all nine islands of the Azorean archipelago (Azores, Portugal) (Borges et al. 2010). It has a large Extent of Occurrence (EOO $=43,265 \mathrm{~km}^{2}$ ) and a relatively large Area of Occupancy $\left(A O O=636-2,228 \mathrm{~km}^{2}\right)$. This species is the most widespread Azorean endemic spider and is particularly abundant from mid to high elevations in bogs, semi-natural pastures and a rare habitat at high elevations, the natural grasslands. The species is also able to occur in intensively managed pastures for dairy cattle. Based upon the large Extent of Occurrence, the good adaptation to human modified habitats, and few threats the species is assessed as Least Concern (LC).

\section{Geographic Range}

\section{Range Description:}

Pardosa acorensis is a wolf spider species occurring in all the nine islands of the Azorean archipelago (Azores, Portugal) (Borges et al. 2010). Within these nine islands it is known from eighteen Natural Forest Reserves: Caldeiras Funda e Rasa and Morro Alto e Pico da Sé (Natural Park of Flores); Caldeira do Faial and Cabeço do Fogo (Natural Park of Faial); Mistério da Prainha, Caveiro and Caiado (Natural Park of Pico); Pico Pinheiro and Topo (Natural Park of S. Jorge); Biscoito da Ferraria, Pico Galhardo, Caldeira Guilherme Moniz, Caldeira Sta. Bárbara e Mistérios Negros and Terra Brava (Natural Park of Terceira); Atalhada, Graminhais and Pico da Vara (Natural Park of S. Miguel) and Pico Alto (Natural Park of S. Maria). The Extent of Occurrence (EOO) is $43,265 \mathrm{~km}^{2}$ and the Area of Occupancy (AOO) is 636-2,228 $\mathrm{km}^{2}$.

\section{Country Occurrence:}

Native, Extant (resident): Portugal (Azores) 


\section{Distribution Map}

Legend

EXTANT (RESIDENT)

POSSIBLY EXTANT (RESIDENT)

$$
45
$$

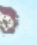

Ponta
anelgida

()

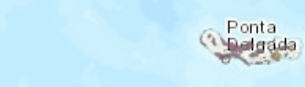

Compiled by:

Azorean Biodiversity Group 2018
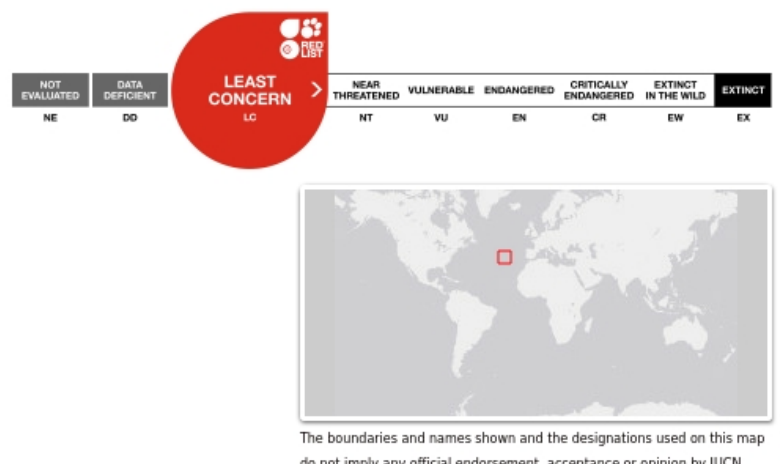


\section{Population}

Pardosa acorensis is a widespread and highly abundant species (Borges and Wunderlich 2008). The species has a stable population and occurs on all nine islands of the Azores, in almost all habitats. We assume no threats for the population since the species is able to occur even in high intensively managed pastures for dairy cattle.

Current Population Trend: Stable

\section{Habitat and Ecology (see Appendix for additional information)}

This is the most generalist Azorean endemic spider, occurring in almost all known Azorean native and arthropogenic habitats (Borges and Wunderlich 2008, Borges et al. 2008). However, the species is particularly abundant from mid to high elevations in bogs, semi-natural pastures and a rare habitat at high elevations, the natural grasslands. The species is also able to occur in intensively managed pastures for dairy cattle. Females were observed carrying egg sacs in spring and summer. Adults are active during the day, as well as at night. The species occurs from sea level to the highest elevation at Pico mountain (Pico island).

\section{Systems: Terrestrial}

\section{Threats (see Appendix for additional information)}

In the past, the species has probably strongly declined due to changes in habitat size and quality (Triantis et al. 2010). Despite major ongoing changes in many of the habitats in which the species occurs, the populations now seem to be stable with no known threats. However, based on Ferreira et al. (2016) the habitat will decline as a consequence of climate change (increasing number of droughts, and habitat shifting and alteration).

\section{Conservation Actions (see Appendix for additional information)}

The species is not protected by regional law, but its habitat is in regionally protected areas (Natural Parks of all nine Azorean islands). Degraded bog areas, degraded due to invasive plant species (particularly Hedychium gardnerianum) and pastures should be restored and a strategy needs to be developed to address the future threat by climate change. Formal education and awareness are needed to allow future investments in restoring bog habitats. Further research is needed into its ecology and life history to obtain adequate information on population size, distribution and trends. It is also necessary to develop a monitoring plan for the wider invertebrate community in its habitat in order to contribute to a potential future species recovery plan, if needed. A monitoring every ten years using the BALA protocol will inform about habitat quality (see e.g. Gaspar et al. 2011).

\section{Credits}

Assessor(s): $\quad$ Borges, P.A.V. \& Cardoso, P.

Reviewer(s): $\quad$ Russell, N.

Contributor(s): $\quad$ Lamelas-López, L. \& Mendonca, E. 
Authority/Authorities: IUCN SSC Spider and Scorpion Specialist Group 


\section{Bibliography}

Borges, P.A.V. and Wunderlich, J. 2008. Spider biodiversity patterns and their conservation in the Azorean archipelago, with descriptions of new species. Systematics and Biodiversity 6(2): 249-282.

Borges, P.A.V., Pimentel, R., Carvalho, R., Nunes, R., Wallon, S. \& Ros Prieto, A. 2017. Seasonal dynamics of arthropods in the humid native forests of Terceira Island (Azores). Arquipelago Life and Marine Sciences 34: 105-122.

Borges, P.A.V., Ugland, K.I, Dinis, F.O. and Gaspar, C. 2008. Insect and spider rarity in an oceanic island (Terceira, Azores): true rare and pseudo-rare species. In: S. Fattorini (ed.), Insect Ecology and Conservation, pp. 47-70. Research Signpost, Kerala, India.

Ferreira, M.T., Cardoso, P., Borges, P.A.V., Gabriel, R., Azevedo, E.B., Reis, F., Araújo, M.B. and Elias, R.B. 2016. Effects of climate change on the distribution of indigenous species in oceanic islands (Azores). Climate Change 138(3-4): 603-615.

Gaspar, C., Gaston, K.J., Borges, P.A.V. and Cardoso, P. 2011. Selection of priority areas for arthropod conservation in the Azores archipelago. Journal of Insect Conservation 15: 671-684.

IUCN. 2020. The IUCN Red List of Threatened Species. Version 2020-3. Available at: www.iucnredlist.org. (Accessed: 10 December 2020).

Triantis, K.A., Borges, P.A.V., Ladle, R.J., Hortal, J., Cardoso, P., Gaspar, C., Dinis, F., Mendonça, E., Silveira, L.M.A., Gabriel, R., Melo, C., Santos, A.M.C., Amorim, I.R., Ribeiro, S.P., Serrano, A.R.M., Quartau, J.A. and Whittaker, R.J. 2010. Extinction debt on oceanic islands. Ecography 33(2): 285-294.

\section{Citation}

Borges, P.A.V. \& Cardoso, P. 2020. Pardosa acorensis. The IUCN Red List of Threatened Species 2020: e.T58048677A58061032. https://dx.doi.org/10.2305/IUCN.UK.2020-3.RLTS.T58048677A58061032.en

\section{Disclaimer}

To make use of this information, please check the Terms of Use.

\section{External Resources}

For Supplementary Material, and for Images and External Links to Additional Information, please see the Red List website. 


\section{Appendix}

\section{Habitats}

(http://www.iucnredlist.org/technical-documents/classification-schemes)

\begin{tabular}{|c|c|c|c|}
\hline Habitat & Season & Suitability & $\begin{array}{l}\text { Major } \\
\text { Importance? }\end{array}$ \\
\hline 1. Forest $->$ 1.4. Forest - Temperate & Resident & Suitable & Yes \\
\hline 3. Shrubland $->$ 3.4. Shrubland - Temperate & Resident & Suitable & Yes \\
\hline 4. Grassland $->$ 4.4. Grassland - Temperate & Resident & Suitable & Yes \\
\hline $\begin{array}{l}\text { 5. Wetlands (inland) -> 5.4. Wetlands (inland) - Bogs, Marshes, Swamps, } \\
\text { Fens, Peatlands }\end{array}$ & Resident & Suitable & Yes \\
\hline 14. Artificial/Terrestrial -> 14.2. Artificial/Terrestrial - Pastureland & Resident & Suitable & No \\
\hline
\end{tabular}

\section{Threats}

(http://www.iucnredlist.org/technical-documents/classification-schemes)

\begin{tabular}{|c|c|c|c|c|}
\hline Threat & Timing & Scope & Severity & Impact Score \\
\hline \multirow[t]{2}{*}{$\begin{array}{l}\text { 11. Climate change \& severe weather }->11.1 \text {. Habitat } \\
\text { shifting \& alteration }\end{array}$} & Future & Whole (>90\%) & $\begin{array}{l}\text { Slow, significant } \\
\text { declines }\end{array}$ & Low impact: 5 \\
\hline & Stresses: & \multicolumn{3}{|c|}{$\begin{array}{l}\text { 1. Ecosystem stresses }->1.2 \text {. Ecosystem degradation } \\
\text { 1. Ecosystem stresses } \rightarrow>1.3 \text {. Indirect ecosystem effects } \\
\text { 2. Species Stresses }->2.1 \text {. Species mortality } \\
\text { 2. Species Stresses }->2.2 \text {. Species disturbance }\end{array}$} \\
\hline \multirow[t]{2}{*}{$\begin{array}{l}\text { 11. Climate change \& severe weather }->11.2 \text {. } \\
\text { Droughts }\end{array}$} & Future & Whole (>90\%) & $\begin{array}{l}\text { Slow, significant } \\
\text { declines }\end{array}$ & Low impact: 5 \\
\hline & Stresses: & \multicolumn{3}{|c|}{$\begin{array}{l}\text { 1. Ecosystem stresses }->1.2 \text {. Ecosystem degradation } \\
\text { 1. Ecosystem stresses }->1.3 \text {. Indirect ecosystem effects } \\
\text { 2. Species Stresses }->2.1 \text {. Species mortality } \\
\text { 2. Species Stresses }->2.2 \text {. Species disturbance }\end{array}$} \\
\hline
\end{tabular}

\section{Conservation Actions in Place}

(http://www.iucnredlist.org/technical-documents/classification-schemes)

\begin{tabular}{|l|}
\hline Conservation Action in Place \\
\hline In-place research and monitoring \\
\hline Action Recovery Plan: No \\
\hline Systematic monitoring scheme: Yes \\
\hline In-place land/water protection \\
\hline Conservation sites identified: Yes, over part of range \\
\hline Percentage of population protected by PAs: $61-70$ \\
\hline
\end{tabular}


Conservation Action in Place

Area based regional management plan: No

Occurs in at least one protected area: Yes

\title{
Conservation Actions Needed
}

(http://www.iucnredlist.org/technical-documents/classification-schemes)

\section{Conservation Action Needed}

1. Land/water protection -> 1.1. Site/area protection

2. Land/water management -> 2.1. Site/area management

2. Land/water management -> 2.3. Habitat \& natural process restoration

4. Education \& awareness $->4$.1. Formal education

4. Education \& awareness $->4.3$. Awareness $\&$ communications

5. Law \& policy -> 5.4. Compliance and enforcement -> 5.4.3. Sub-national level

\section{Research Needed}

(http://www.iucnredlist.org/technical-documents/classification-schemes)

\author{
Research Needed \\ 1. Research $->1.2$. Population size, distribution \& trends \\ 1. Research -> 1.3. Life history \& ecology \\ 3. Monitoring $->$ 3.1. Population trends \\ 3. Monitoring -> 3.4. Habitat trends
}

\section{Additional Data Fields}

\section{Distribution}

Estimated area of occupancy (AOO) $\left(\mathrm{km}^{2}\right)$ : 636-2228

Continuing decline in area of occupancy (AOO): No

Extreme fluctuations in area of occupancy (AOO): Unknown

Estimated extent of occurrence (EOO) $\left(\mathrm{km}^{2}\right)$ : 43265

Continuing decline in extent of occurrence (EOO): No

Extreme fluctuations in extent of occurrence (EOO): No

Continuing decline in number of locations: No

Extreme fluctuations in the number of locations: Unknown 


\section{Distribution}

Lower elevation limit $(\mathrm{m}): 0$

Upper elevation limit (m): 2,339

\section{Population}

Continuing decline of mature individuals: No

Population severely fragmented: No

\section{Habitats and Ecology}

Continuing decline in area, extent and/or quality of habitat: No

Generation Length (years): 1 


\section{The IUCN Red List Partnership}

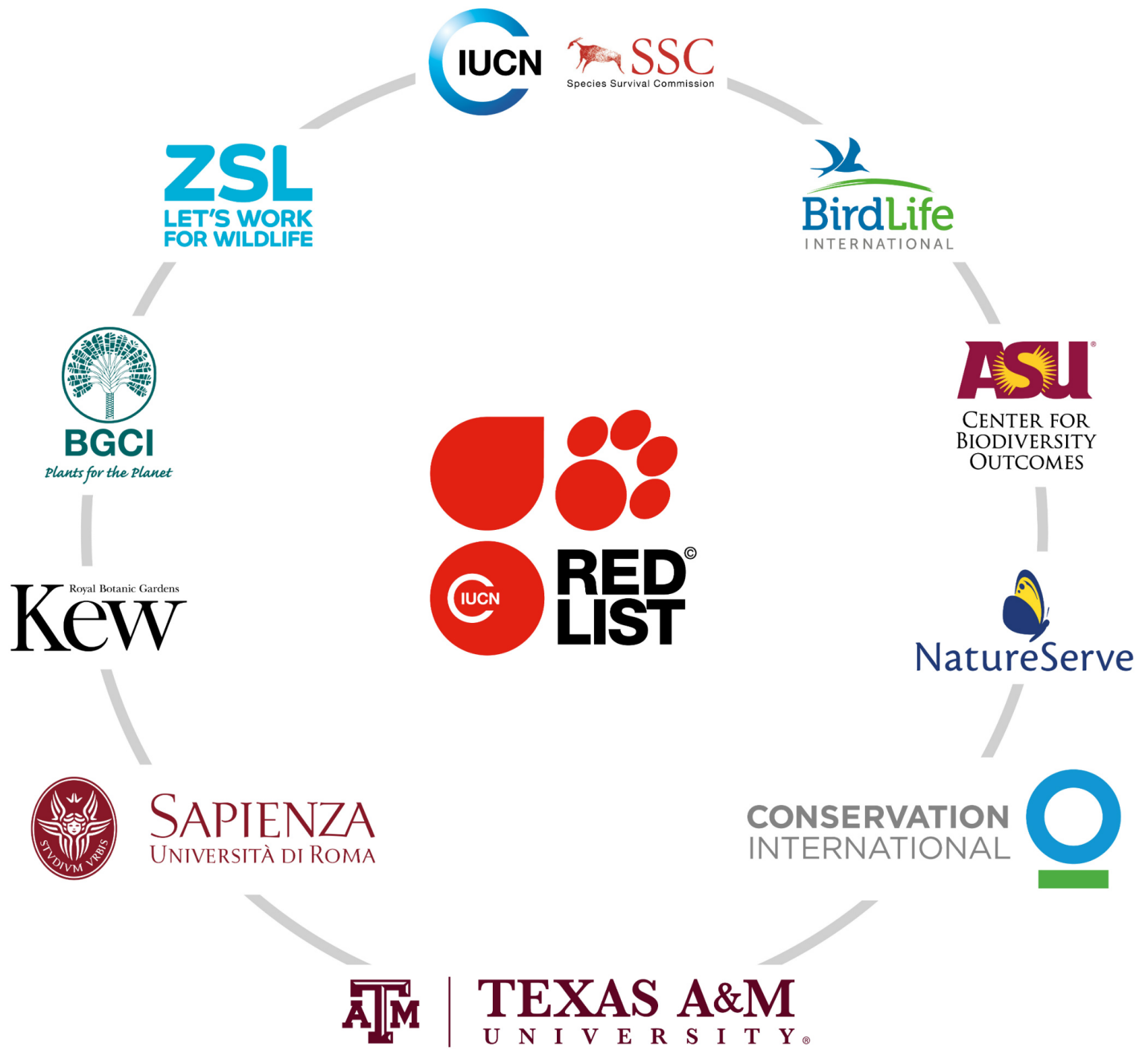

The IUCN Red List of Threatened Species ${ }^{\mathrm{TM}}$ is produced and managed by the IUCN Global Species Programme, the IUCN Species Survival Commission (SSC) and The IUCN Red List Partnership.

The IUCN Red List Partners are: Arizona State University; BirdLife International; Botanic Gardens Conservation International; Conservation International; NatureServe; Royal Botanic Gardens, Kew; Sapienza University of Rome; Texas A\&M University; and Zoological Society of London. 